\title{
INHIBITION OF $\beta$-SITOSTEROL ON INTESTINAL CHOLESTEROL ABSORPTION IN RAT USING IN VIVO DUAL ISOTOPE RATIO METHOD
}

\author{
Yoshihiro Shidoj, Makoto WATANABE, Tsuneyuki OKU, ${ }^{1}$ \\ Yasutoshi, Muto, ${ }^{2}$ and Norimasa HosoYA ${ }^{1}$ \\ ${ }^{1}$ Department of Nutrition, School of Health Sciences, \\ Faculty of Medicine, University of Tokyo, \\ Hongo, Bunkyo-ku, Tokyo 113, Japan \\ ${ }^{2}$ Department of Medicine, Gifu University, School of Medicine, \\ Tsukasa-cho, Gifu 500, Japan
}

(Received January 14, 1980)

\begin{abstract}
Summary The inhibitory effects of $\beta$-sitosterol on intestinal cholesterol absorption were studied by means of a dual isotope plasma ratio method (in vivo), which is a new technique for the measurement of cholesterol absorption, as well as a ligated-loop method (in situ). The results obtained were as follows:

1. The absorption of $\beta$-sitosterol itself was significantly less than cholesterol. Cholesterol was selectively absorbed from rat intestine.

2. When 100 to $1,000 \mu \mathrm{g}$ of $\beta$-sitosterol were added to the dose solution containing $10 \mu \mathrm{g}$ of cholesterol, cholesterol absorption by the in vivo experiment decreased with the increase of additional $\beta$-sitosterol.

3. A similar inhibitory effect of $\beta$-sitosterol was observed by the in situ ligated-loop method.

These results suggest that $\beta$-sitosterol actually inhibits cholesterol absorption in the physiological state of an animal.

Keywords dual isotope, ligated-loop, selective absorption, $\beta$-sitosterol, cholesterol, intestinal (absorption), inhibition
\end{abstract}

Some plant sterols, such as $\beta$-sitosterol and stigmasterol, are thought of as agents preventing hypercholesterolemia. The lowering effect of dietary $\beta$-sitosterol on serum cholesterol of rat $(1)$, chick $(2)$ and man $(3,4)$ suggest that $\beta$-sitosterol may inhibit the intestinal absorption of cholesterol. Mattson et al.(5) originally showed the effect of $\beta$-sitosterol in rats with lymph-duct fistula, which gave a direct estimation of cholesterol absorption from the intestinal tract. However, Sylvén and Borgström demonstrated contradictory results on intestinal absorption of cholesterol and $\beta$-sitosterol (6) using the same methods. It is not yet clear whether the

${ }^{1}$ 四童子好広, 渡部 誠, 奥 恒行, ${ }^{2}$ 武藤泰敏, ${ }^{1}$ 細谷憲政 
inhibitory effect of $\beta$-sitosterol would actually occur on the intestinal absorbing process of cholesterol or not.

Recently, Zilversmit et al. have developed an in vivo dual isotope plasma ratio method as a new technique for the measurement of cholesterol absorption in rat $(7,8)$. The method has been evaluated as very reliable and useful in the physiological state of animals, and even on man(9). Therefore, it seemed interesting to investigate the effect of $\beta$-sitosterol on cholesterol absorption using the dual isotope ratio method.

The present paper describes the $\beta$-sitosterol effect on intestinal cholesterol absorption by not only the in vivo dual isotope ratio method but the in situ ligatedloop technique.

\section{METHODS}

1. Chemicals and animals. $7-\left[{ }^{3} \mathrm{H}\right]$-Cholesterol (s.a. $21.5 \mathrm{Ci} / \mathrm{mmol}$ ) was obtained from New England Nuclear Co. (Boston, MA), and 4- $\left[{ }^{14} \mathrm{C}\right]$-cholesterol (s.a. $0.057 \mathrm{Ci} / \mathrm{mmol}$ ), $22,23-\left[{ }^{3} \mathrm{H}\right]$ - $\beta$-sitosterol (s.a. $58 \mathrm{Ci} / \mathrm{mmol}$ ) and $4-\left[{ }^{14} \mathrm{C}\right]-\beta$-sitosterol $(0.053 \mathrm{Ci} / \mathrm{mmol})$ were obtained from Amersham $/$ Searle Co. (Arlington Height, IL). The purity of these radioactive sterols was tested by thin layer chromatography on silica gel G (Merck Co., Darmstadt, Germany) with the solvent system of benzene : ethylacetate $=2: 1(\mathrm{v} / \mathrm{v})$. Sterols with a purity of more than $93 \%$ were used in all experiments. The micellar dose solutions containing radioactive cholesterol $(1.0 \mu \mathrm{Ci} / 0.5 \mathrm{ml})$ or $\beta$-sitosterol $(1.0 \mu \mathrm{Ci} / 0.5 \mathrm{ml})$ were prepared by dissolving various amounts of the corresponding non-radioactive sterol and $5 \mathrm{~mm}$ glycerol monooleate (Sigma Chem. Co., St. Louis, MO) in $50 \mathrm{~mm}$ sodium phosphate buffer ( $\mathrm{pH}$ 6.3) containing $5 \mathrm{~mm}$ glycochenodeoxycholic acid (Tokyo Tanabe Co., Tokyo). These solutions were incubated at $37^{\circ} \mathrm{C}$ overnight to produce stable micellar particles.

Sprague-Dawley rats weighing 250-300 g were fed with a commercial chow (Oriental Yeast Co., Tokyo) ad libitum, and fasted for $24 \mathrm{hr}$ before the experiments.

2. Dual isotope plasma ratio method (in vivo). The measurement of cholesterol and $\beta$-sitosterol absorption from the intestine were carried out by the dual isotope ratio method $(8,9)$ with slight modifications as follows; under light anesthesia with ether, the abdominal cavity was opened by incision, and $1.0 \mu \mathrm{Ci}$ of $\left[{ }^{14} \mathrm{C}\right]$-cholesterol or $\left[{ }^{14} \mathrm{C}\right]-\beta$-sitosterol in $0.5 \mathrm{ml}$ of micellar dose solution was administered into the duodenum. Immediately after the dosage, $1.0 \mu \mathrm{Ci}$ of $\left[{ }^{3} \mathrm{H}\right]$ cholesterol or $\left[{ }^{3} \mathrm{H}\right]$ - $\beta$-sitosterol dispersed in $0.5 \mathrm{ml}$ of serum obtained previously from the same animal was also injected into the left external jugular vein (I.V. dose). Thereafter, the rat was fed with the same diet and water ad libitum in a wire cage, and $2 \mathrm{ml}$ of blood were collected from the right external juglar vein of the rat with heparinized syringes at 48,72 and $96 \mathrm{hr}$. The radioactive sterols were extracted from the plasma samples $(1 \mathrm{ml}$ each) with $3 \mathrm{ml}$ of ethanol : hexane $=2: 1(\mathrm{v} / \mathrm{v})$ after saponification with $50 \% \mathrm{KOH}$ at $50^{\circ} \mathrm{C}$ for $30 \mathrm{~min}$. Both radioactivities of $\left[{ }^{3} \mathrm{H}\right]$ - and 
$\left[{ }^{14} \mathrm{C}\right]$-sterol were then determined simultaneously in a toluene-based scintillation cocktail containing $0.4 \%$ Omnifluor (New England Nuclear Co., Boston, MA) by a Packard Tri-Carb liquid scintillation spectrometer, Model 3380 (Packard Co., Downers Grove, IL). Percent absorption of cholesterol or $\beta$-sitosterol was calculated by the formula as follows:

$$
\% \text { absorption }=\frac{\left[\text { plasma }\left[{ }^{14} \mathrm{C}\right](\mathrm{DPM}) /\left[\operatorname{dosed}\left[{ }^{14} \mathrm{C}\right](\mathrm{DPM})\right]\right.}{\left[\text { plasma }\left[{ }^{3} \mathrm{H}\right](\mathrm{DPM})\right] /\left[\operatorname{dosed}\left[{ }^{3} \mathrm{H}\right](\mathrm{DPM})\right]} \times 100
$$

3. Ligated-loop method (in situ). The measurements for intestinal mucosal uptake of sterols were carried out by the (in situ) ligated-loop method of Sylvén (10). After an animal was anesthetized with nembutal $(30 \mathrm{mg} / \mathrm{kg}), 4$ to 6 segments of 4-cm length were made in the jejunum of an animal with an intact current of blood and lymph. One-hundredth $\mu \mathrm{Ci}$ of $\left[{ }^{14} \mathrm{C}\right]$-cholesterol or $\left[{ }^{3} \mathrm{H}\right]-\beta$ sitosterol in $0.5 \mathrm{ml}$ of dose solution was injected into each segment, and then incubated in the body for $30 \mathrm{~min}$ after the abdominal wall had been closed. At the end of the incubation, each segment of the loop was washed with $2 \mathrm{ml}$ of ice-chilled physiological saline. Then, the tissue was further washed 5 times with $2 \mathrm{ml}$ of icechilled $5 \mathrm{~mm}$ sodium deoxycholate in saline to remove the sterols that remained on the surface of the mucosa. Finally, each washed tissue was weighed (200-400 mg), then the radioactive sterols were extracted with $9 \mathrm{ml}$ of chloroform: methanol= $2: 1(\mathrm{v} / \mathrm{v})$, as described by Folch et al.(11). After the solvent had dried, the radioactivities were determined, and the amount of sterol incorporated into the tissue was calculated and expressed as $\mu \mathrm{g} / 100 \mathrm{mg}$ tissue $/ 30 \mathrm{~min}$.

\section{RESULTS}

\section{Selective absorption of cholesterol and $\beta$-sitosterol}

$\beta$-Sitosterol absorption was measured by the dual isotope ratio method, since different results on intestinal absorption of $\beta$-sitosterol have been reported by some laboratories using other methods such as a balance study $(12,13)$ and lymph collection (6). The absorption ratio of $\beta$-sitosterol was $5.4 \pm 1.6 \%$ (in $500 \mu \mathrm{g}$ dose) and that of cholesterol was $44.2 \pm 3.8 \%$ (in $500 \mu \mathrm{g}$ dose) (Table 1). These results show that $\beta$-sitosterol is resistant to intestinal absorption, and cholesterol is selectively absorbed from rat intestine.

\section{Effect of $\beta$-sitosterol on the absorption and mucosal uptake of cholesterol}

In order to observe the $\beta$-sitosterol effect on cholesterol absorption, 100 to $1,000 \mu \mathrm{g}$ of $\beta$-sitosterol (Gaskuro Co., Tokyo, purity $98 \%$ ) were added to $10 \mu \mathrm{g}$ of $\left[{ }^{14} \mathrm{C}\right]$-cholesterol $(1.0 \mu \mathrm{Ci})$ in a $0.5 \mathrm{ml}$ dose solution, and cholesterol absorption was measured by the dual isotope ratio method. As shown at left in Fig. 1, cholesterol absorption clearly decreased with an increase of additional $\beta$-sitosterol. The absorption ratio of cholesterol was about $48.3 \%$ of control in the presence of 
Table 1. The selective absorption of cholesterol and $\beta$-sitosterol.

\begin{tabular}{lcc}
\hline & Cholesterol & $\beta$-Sitosterol \\
\hline DIRM (in vivo) & $44.2 \pm 3.8^{\mathrm{a}}$ & $5.4 \pm 1.6^{\mathrm{a}}$ \\
Ligated-loop (in situ) & $10.3 \pm 2.7^{\mathrm{b}}$ & $3.5 \pm 0.7^{\mathrm{b}}$ \\
\hline
\end{tabular}

Five hundred $\mu \mathrm{g}$ of $\left[{ }^{14} \mathrm{C}\right]$-cholesterol or $\left[{ }^{14} \mathrm{C}\right]-\beta$-sitosterol in a $0.5 \mathrm{ml}$ dose solution were given into the duodenum and \% absorption of sterol was measured by DIRM as described elsewhere. In the in situ ligated-loop method, $100 \mu \mathrm{g}$ of $\left[{ }^{14} \mathrm{C}\right]$-cholesterol or $\left[{ }^{3} \mathrm{H}\right]-\beta$-sitosterol in a $0.5 \mathrm{ml}$ of dose solution were injected into the jejunal segment and the amount of sterol incorporated in mucosa was measured. The values were expressed as $\mu \mathrm{g}$ of sterol per $100 \mathrm{mg}$ tissue per $30 \mathrm{~min}$ incubation.

a $\%$ absorption per rat. ${ }^{b} \mu \mathrm{g}$ of sterol incorporated per $100 \mathrm{mg}$ tissue per $30 \mathrm{~min}$.

Dual Isotope Plasma Ratio Method

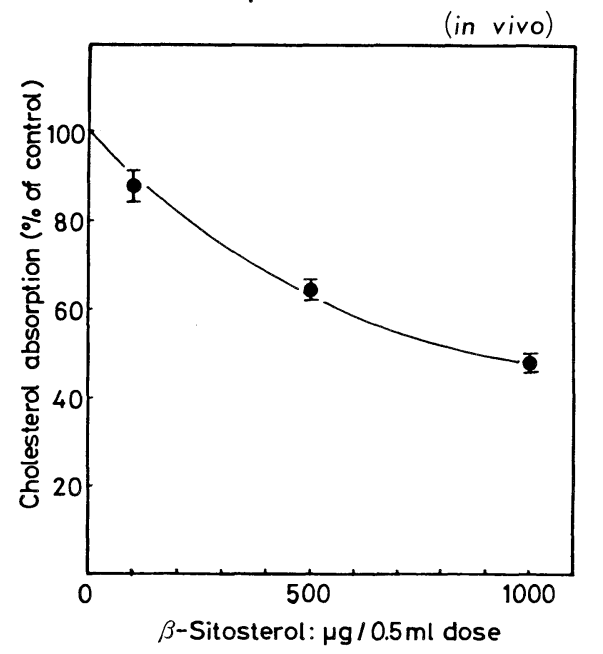

Ligated-loop Method

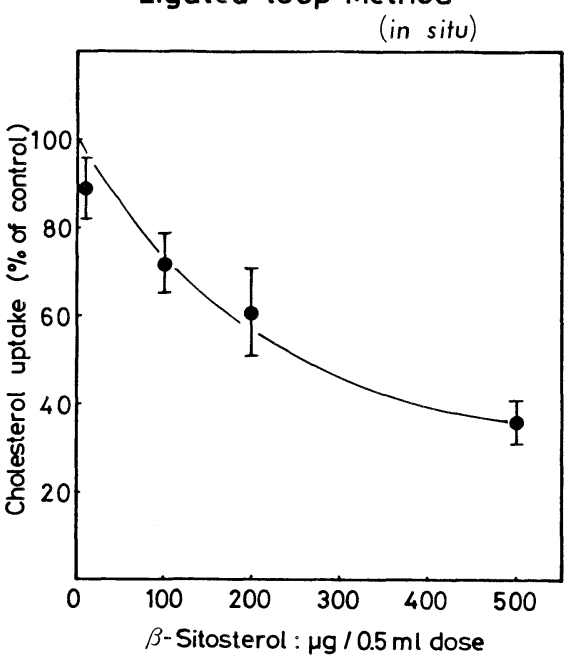

Fig. 1. Inhibitory effect of $\beta$-sitosterol on cholesterol absorption and mucosal uptake. The cholesterol absorption ratio in the administration of $10 \mu \mathrm{g}$ of cholesterol in a $0.5 \mathrm{ml}$ dose solution was measured by DIRM in the presence of 0 (control), 100 , 500 and $1,000 \mu \mathrm{g}$ of $\beta$-sitosterol (left in Fig. 1). The values are expressed as $\%$ of control. Cholesterol uptake into the jejunal mucosa of a segment was measured by the in situ ligated-loop method in the presence of 0 (control), 10, 100, 200 and $500 \mu \mathrm{g}$ of $\beta$-sitosterol (right in Fig. 1). Cholesterol given into a segment was $10 \mu \mathrm{g}$ in a $0.5 \mathrm{ml}$ dose solution. The values ( $\mu \mathrm{g}$ of incorporated cholesterol/100 $\mathrm{mg}$ tissue $/ 30 \mathrm{~min}$ ) were also expressed as $\%$ of control.

$1,000 \mu \mathrm{g}$ of $\beta$-sitosterol (100 times the amount of cholesterol). The $\beta$-sitosterol effect on cholesterol absorption was also studied by the ligated-loop technique. 
When 10 to $500 \mu \mathrm{g}$ of $\beta$-sitosterol were added to the dose solution containing $10 \mu \mathrm{g}$ of cholesterol, the mucosal uptake of cholesterol decreased with an increase of additonal $\beta$-sitosterol (right in Fig. 1). The cholesterol uptake was about $36 \%$ of the control in the presence of $500 \mu \mathrm{g}$ of $\beta$-sitosterol (50 times the amount of cholesterol).

These results strongly indicate that $\beta$-sitosterol has an inhibitory effect on intestinal cholesterol absorption. Furthermore, the results support that both the methods, in vivo dual isotope ratio method and in situ ligated-loop method, bring similar results of intestinal absorption and mucosal uptake of cholesterol.

\section{DISCUSSION}

Sylvén and Borgström(6) have demonstrated that $\beta$-sitosterol showed no inhibitory effect on cholesterol absorption in rat with lymph duct fistulae. However, the result seems to occur in animals in which cholesterol metabolism might lead to an unsteady state during the long-term collection of lymph. Actually, the absolute value of absorbed cholesterol in their experiment was much lower than that of other groups $(5,14)$. On the other hand, Mattson et al. (5) showed the inhibitory effect of $\beta$-sitosterol in rats with lymph duct fistulae when an excess amount of $\beta$-sitosterol (more than $30 \mathrm{mg}$ per rat) was administered. The inhibitory effect of $\beta$-sitosterol observed in their experiment may be related to the reduction in cholesterol solubility to disturb the micell formation in a stage before absorption. However, our results also indicated that cholesterol absorption and mucosal uptake were decreased in the presence of $\beta$-sitosterol, in spite of the total sterol concentration being much lower ( $3 \mathrm{~mm}$ or less in $5 \mathrm{~mm}$ bile acid) as Borgström has reported(15). In our results, $\beta$-sitosterol seems to have other inhibitory mechanisms than the reduction in cholesterol solubility on intestinal cholesterol absorption. Furthermore, similar inhibitory effects of $\beta$-sitosterol observed by both the in vivo dual isotope ratio method and in situ ligated-loop technique appears to suggest that the inhibition takes palce at the stage of mucosal uptake in the absorption process of cholesterol. As $\beta$-sitosterol actually led to a decrease in cholesterol uptake in the in situ experiment, while the cholesterol incorporated into mucosa was not detected in the lymph or blood during the 30 -min incubation. The selective absorption of sterols would also be related to the stage of mucosal uptake as suggested elsewhere (16).

From the present study, it was demonstrated that $\beta$-sitosterol inhibited the absorption of cholesterol in the physiological state. However, further observations are necessary to clarify the mechanism of the inhibitory effect of $\beta$-sitosterol on cholesterol absorption.

\section{REFERENCES}

1) Alfin-Slater, R. B., Well, A. F., Aftergood, L., Melnik, D., and Deuel, H. J., Jr. Vol. 26, No. 2, 1980 
(1954): The effect of plant sterols on cholesterol levels in the rat. Circulation Res., 2, 471-475.

2) Sklan, D., Dahan, M., Budowski, P., and Hurwitz, S. (1977): Differential absorption of endogenous and exogenous cholesterol in the chick as affected by dietary oil level and phytosterols. J. Nutr., 107, 1996-2000.

3) Lees, A. M., Mok, H. Y. K., Lees, R. S., McCluskey, M. A., and Grundy, S. M. (1977): Plant sterols as cholesterol-lowering agents: clinical trials in patients with hypercholesterolemia and studies of sterol balance. Atherosclerosis, 28, 325-338.

4) Kudchodkar, B. J., Horlick, L., and Sodhi, H. S. (1976): Effects of plant sterols on cholesterol metabolism in man. Atherosclerosis, 23, 239-248.

5) Mattson, F. H., Volpenhein, R. A., and Erickson, B. A. (1977): Effect of plant sterol esters on the absorption of dietary cholesterol. J. Nutr., 107, 1139-1146.

6) Sylvén, C., and Borgström, B. (1969): Absorption and lymphatic transport of cholesterol and sitosterol in the rat. J. Lipid Res., 10, 179-182.

7) Zilversmit, D. B. (1972): A single blood sample dual isotope method for the measurement of cholesterol absorption in rats. Proc. Soc. Exp. Biol. Med., 140, 862-865.

8) Zilversmit, D. B., and Huges, L. B. (1974): Validation of a dual-isotope plasma ratio method for measurement of cholesterol absorption in rats. J. Lipid Res., 15, 465-473.

9) Samuel, P., Crouse, J. R., and Ahrens, E. H., Jr. (1978): Evaluation of an isotope ratio method for measurement of cholesterol absorption in man. J. Lipid Res., 19, 82-93.

10) Sylvén, C. (1970): Influence of blood supply on lipid uptake from micellar solutions by the rat small intestine. Biochim. Biophys. Acta, 203, 365-375.

11) Folch, J., Lees, M., and Sloane Stanley, G. H. (1956): A simple method for the isolation and purification of total lipids from animal tissues. J. Biol. Chem., 226, 497-509.

12) Subbiah, M. T. R. (1973): Dietary plant sterols. Am. J. Clin. Nutr., 26, 219-225.

13) Glover, J., and Morton, R. A. (1958): The absorption and metabolism of sterols. Brit. med. Bull., 14, 226-233.

14) Vahouny, G. V., Ito, M., Blendermann, E. M., Gallo, L. L., and Treadwell, C. R. (1977): Puromycin inhibition of cholesterol absorption in the rat. J. Lipid Res., 18, $745-752$.

15) Borgström, B. (1967): Partition of lipids between emulsified oil and micellar phases of glyceride-bile salt dispersions. J. Lipid Res., 8, 598-608.

16) Sylvén, C., and Nordström, C. (1970): The site of absorption of cholesterol and sitosterol in the rat small intestine. Scand. J. Gastroent., 5, 57-63. 